The Social Sciences 12 (12): 2254-2259, 2017

ISSN: $1818-5800$

(C) Medwell Journals, 2017

\title{
The Effect of Student's Knowledge and Skill on the Readiness of AEC Competition
}

\author{
Setyabudi Indartono and F. Nahiyah Jaidi \\ Universitas Negeri Yogyakarta, Yogyakarta, Indonesia
}

\begin{abstract}
This study is aimed to explore the effect of knowledge and skill on the readiness of Indonesian student of higher education toward the competition at Asean Economic Community (AEC). This study employs 3900 student from 42 Universities. Multiple regressions are used to analyze the data. The result shows that student's knowledge and skill are significantly effect on their readiness toward AEC competition.
\end{abstract}

$\underline{\text { Key words: Knowledge, skill, competition readiness, AEC, regressions, significant effect }}$

\section{INTRODUCTION}

Winning to the competitions are closely related to the psychological readiness of parties involved. It is believed to be a part of an integral personal structure which includes a number of psychological characteristics reflecting one's inner state such as motivation, needs, emotions, reflection (Babushkina et al., 2011). The psychological readiness is needed to be a pre-competition preparation. It may strengthen the degree they perceive themselves to be ready in facing their competitors (Maire et al., 2007). However, students are likely to avoid the competitive situations where they did not believe chances were good that they would win (Firmin et al., 2011). In a global challenge, students have emerged as a priority human capital resource and one highly acceptable to host-country employers. It is believed that students make attractive global employees. However, students are required to be young and expected to possess advanced have language ability and relevant professional training or experience, complete a domestic qualification aligned with the human capital requirements of local employers.

Asean Economic Community (AEC) requires the countrie's member to fight each others in order to integrate their resources. Economic liberalization agreements, i.e., $\mathrm{AEC}$ is believed to promote the rescaling of economic governance, involving regulatory changes that may radically redistribute power and resources. Various programs are delivered to strengthen and protect the interests of each AEC countries (Soesastro, 2003). In the case of service liberalization however, there are a number of restrictions on foreign labor in the service sectors. Scholars report that Indonesia and Malaysia has highest restrictiveness index. Indonesian government has also identified the key challenges for the country in the implementation of the AEC, i.e., customs modernization, standards and conformance and infrastructure development (Soesastro, 2008). AEC countries try to update their implementation status of the standard and conformance. It is believed that it will be equipped to support competitive industries and standards that would reflect how the government would support and cultivate a culture of quality consciousness in the production of goods and services. Hence, ability to take advantage of the AEC will highly depend on the skills of workforce, especially the younger generation (Kee et al., 2009).

Workforce competition issues: AEC's agreement allows professional employees of a firm located in one ASEAN country to research temporarily. It is required each member-state to change professional labor regulations to afford the mutual recognition of professional qualifications, allowing the employee to research without re-qualifying in every national jurisdiction. However, their content varied wildly. Thailand's Medical Council was dominated by scarce and consequently well-paid, local doctors who feared greater competition from immigrants. Malaysia, Philippines, Singapore and Thailand practice freely in each other's jurisdictions for architectural services (Sumano, 2013).

All of Indonesia Economic major sectors promoted Gross Domestic Product (GDP). It is shows that the services sector has a better contribution to GDP rather than others. It increases $70 \%$ rapidly from $2007-2015$. It is indicated by the increase $25 \%$ of employment rate (Fig. 1). Service Sector and it's competitiveness of Indonesian workers is reported based on the global competitiveness Index. It measures the set of institutions, policies and factors that set the sustainable current and medium-term levels of economic prosperity. Indonesia is ranked 37th in 2015. It is below the others ASEAN countries such as Thailand, Malaysia and Singapore. The rank increases 3 points from the ranked 34 th of the previous year. It means that Indonesia competitiveness decreases compare

Corresponding Author: Setyabudi Indartono, Universitas Negeri Yogyakarta, Yogyakarta, Indonesia 

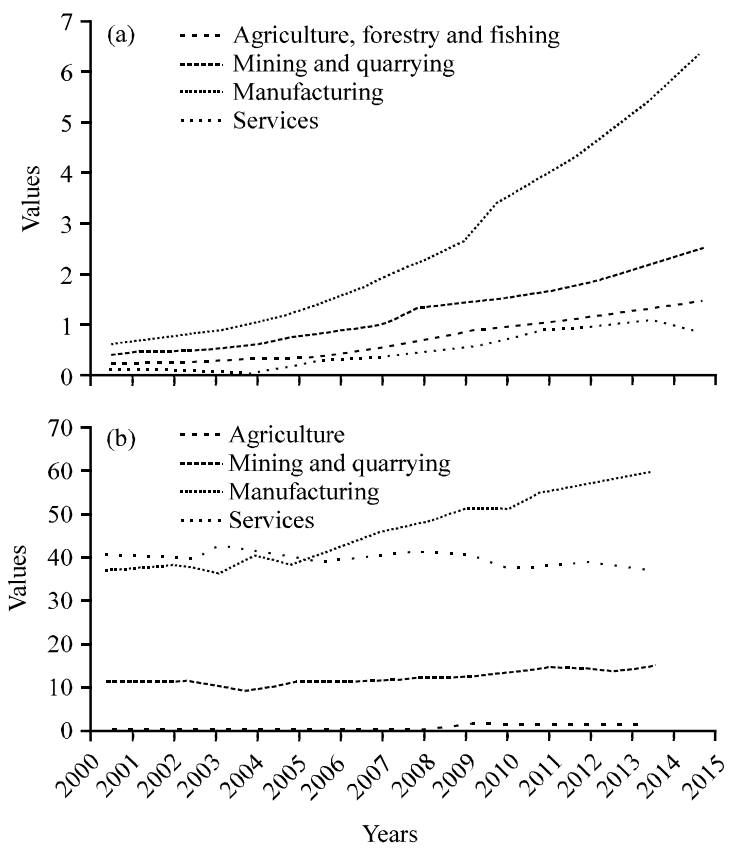

Fig. 1: GDP and workforce composition based sectors: a) GDP and b) workforce; http://www.adb.org/ publications/key-indicators-asia-and-pacific-2016

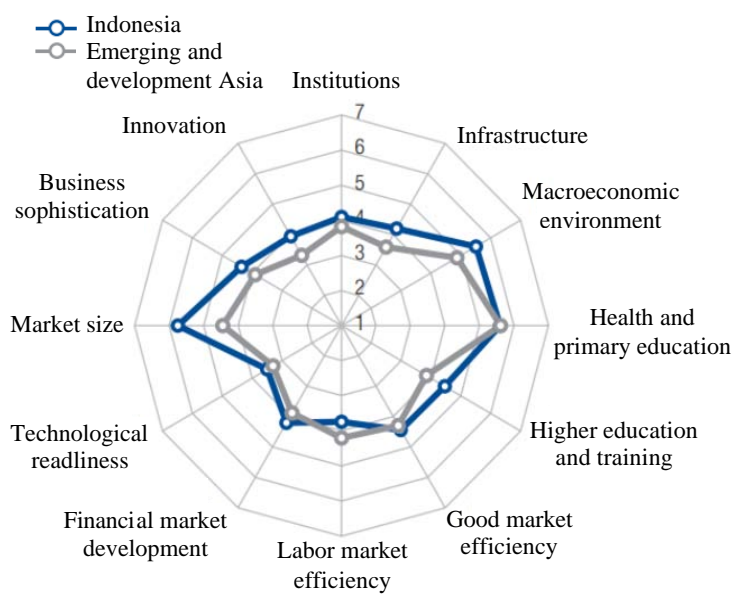

Fig. 2: Global competitiveness index of Indonesia

\begin{tabular}{lcc}
\multicolumn{3}{l}{ Table 1: GCI among development countries } \\
\hline Years & Level of GCI & Index of GCI \\
\hline $2011-2012$ & 46 & 4.40 \\
$2012-2013$ & 50 & 4.40 \\
$2013-2014$ & 38 & 4.53 \\
$2014-2015$ & 34 & 4.57 \\
$2015-2016$ & 37 & 4.50 \\
\hline
\end{tabular}

to the other countries. However, Indonesia showed better conditions of GCI among development countries, particularly from the market size indicator (Fig. 2 and Table 1).
This is concerning for Indonesia, given the increased attention worldwide on the services sector as a likely source of growth, the contribution of the services sector to the competitiveness of other sectors and the opportunities available for capturing the gains from innovation and change in services (Findlay and Pangestu, 2016). It is suggested to increase transparency and policy information, capture the opportunities from international commitments and explore the potential of new technology and urbanization. While others suggest policymakers need to focus on ensuring an effective, transparent and accountable system of governance (Mishra et al., 2016). A greater availability of investible funds brought about by rising savings and capital formation and growing opportunities brought about by rising consumption are able to rise prosperity, wages and improve conditions can foster a culture of entrepreneurship.

Knowledge and skill on the AEC competition: AEC requires highly knowledge and skill mobility among countries member. It is included challenges and opportunities such as portable qualifications, increased access to the skilled labor market, adequate supply of skilled professionals and strong demand for skilled professionals. The challenge ASEAN member states face is threefold. First, the complexity of the qualifications recognition process essentially discourages professionals who move within the region from having their professional and academic credentials assessed and recognized. Second, professionals face restricted access to the ASEAN labor market due to national-level barriers such as constitutional provisions reserving particular occupations for nationals and complex and opaque requirements and procedures for employment visas. Finally, many professionals themselves have limited interest in moving within the region due to perceived cultural, language and socio-economic differences (Papademetriou et al., 2016).

According to the United Nation's most recent estimates, $70 \%$ of the 9.5 million migrants in the ASEAN region in 2013 (or 6.5 million people) were from other ASEAN member states. About $97 \%$ of the 6.5 million intra-ASEAN migrants in 2013 circulated between just three countries: Thailand, Malaysia and Singapore. One million migrants each from Indonesia, Malaysia and Lao People's Democratic Republic have migrated to Malaysia, Singapore and Thailand, respectively. The philippines is also one of the largest sources of temporary labor migrants in the world but the majority of its foreign 
workers go to the Middle East, particularly to the gulf states, since countries in this region have opened their borders to all rsearchers, regardless of skill level. Thailand, nearly all migrants (97\%) are from other ASEAN countries but only $3 \%$ of these workers are considered to be highly skilled. The majority of Malaysian's skilled and professional researchers come from beyond the ASEAN region, only $10 \%$ are working in high-skilled occupations. AEC allows tourism occupations will be granted automatic recognition as they move within the region while professionals in engineering, nursing, architecture, medicine and dentistry are eligible after completing compensatory qualifications standards and working practices between the origin and destination country. Accordingly scholars suggest that recognizing qualifications from differences between countries should be concern to what a professional must know to practice his or her profession, grant automatic recognition for each occupation across each of the signatory countries, recognition of a school diploma is not the same as recognition of qualifications or the right to practice in regulated occupations and developed labor-intensive policy (Papademetriou et al., 2016).

Based on Vuong et al. (2014) competition readiness is ability to observe and forecast threats/risks as well as estimate future costs and benefits of pursuing innovation. It requires various skills and knowledge to generate those processes and requirements. Whereas Blumenstein and Orbach (2016) believed that to achieve the international level recognitions, one may have sufficient supports of personality characteristics, knowledge and skills. The skills are related to people communication, relationship, leadership and experience in psychological preparation. The knowledge is included theory and methodology of competition areas, technical and tactical preparations and in managing and organizing practice and competition. Hence, this study proposes that the student's knowledge and skill are significantly effect on their readiness of AEC competition.

\section{MATERIALS AND METHODS}

This study employs 3900 students from 42 universities and 21 cities of entire of Indonesia. It is included $55.6 \%$ male students, $32.6 \%$ students at 3 rd semester, $30.9 \%$ at 5 th semester and $35.9 \%$ at 7 th semester and student from various study backgrounds (Table 2). This study covered $26 \%$ study programs with "A" accreditation and $61 \%$ with "B" accreditation.

The instruments used are developed based on forum group discussion from university, HRD of industries and
Table 2: Study program of respondents

\begin{tabular}{lc}
\hline Study background & Percentage \\
\hline Civil engineering & 15.3 \\
Mechanical engineering & 13.2 \\
Electrical engineering & 10.1 \\
Geological engineering & 0.2 \\
Industrial engineering & 6.4 \\
Architectural engineering & 10.1 \\
Nursing & 5.8 \\
Medical & 8.8 \\
dentistry & 7.0 \\
Tourism & 2.6 \\
Surveying & 0.4 \\
Accounting & 20.1 \\
\hline
\end{tabular}

representative of Ministry of Manpower of the republic of Indonesia. The samples questions are "my knowledge is sufficient enough for the MEA labor competition", "I am master at the management and leadership skills" and "I am ready to compete the MEA labor competition". A 5-point rating scale was used to evaluate skill and knowledge. A higher score indicated that participant represent high skill and knowledge of competencies. A 9-point rating scale was used to evaluate competition readiness. A higher score of indicated that participant have fully ready to compete toward the competition at Asean Economic Community (AEC).

Measure validation: Confirmatory Factor Analysis (CFA) is adopted to test for the quality and adequacy of the measurement model. In accordance with the two-step procedure suggested by Anderson and Gerbing (1988) Confirmatory Factor Analysis (CFA) is performed to examine reliability, convergent and discriminant validity of the multi-item construct measures. Initial specification search led to deletion of some of the items in the constructs scale in order to provide acceptable fit. Selected statistics for the final overall-model assessment show acceptable fit of the measurement model.

Table 3 shows the analysis of loading factor. It is found that 3 valid items to explore the knowledge, 20 from 28 items are valid to measure skill and 2 valid items are represented the readiness questionnaire. There are 2 item of knowledge and 8 items of skill are rejected. Validity tests included convergent and divergent validity. The result of the convergent validity test is accepted. It's assessed by checking individual item loadings for each corresponding research constructing (Table 3). It is found that the values of factor loadings are above the recommended value of 0.5. Further, Average Variance Constructed (AVE) values are found $>0.5$ for competition readiness and knowledge. Hence, based on Fornell and Larcker (1981) the convergent validity is accepted (Table 4).

Discriminant validity is indicated by correlation between variables and the values of the square root 
The Soc. Sci., 12 (12): 2254-2259, 2017

Table 3: Loading factor of constructs

\begin{tabular}{|c|c|c|c|c|}
\hline Factors & Items & Skill & Knowledge & Readiness \\
\hline I understand the consequence of Asean economic community competition & CR1 & & & 0.830 \\
\hline I am ready to compete toward the competition at Asean economic community & CR2 & & & 0.798 \\
\hline $\begin{array}{l}\text { My knowledge was acquired in higher education is enough to compete toward the } \\
\text { competition at Asean economic community }\end{array}$ & $\mathrm{K} 1$ & & 0.806 & \\
\hline $\begin{array}{l}\text { My knowledge was acquired in higher education is appropriate to compete toward } \\
\text { the competition at Asean economic community }\end{array}$ & $\mathrm{K} 2$ & & 0.759 & \\
\hline $\begin{array}{l}\text { My knowledge was acquired in higher education is sufficient to compete toward the } \\
\text { competition at Asean economic community }\end{array}$ & K3 & & 0.639 & \\
\hline I able to work individually & S1 & & & \\
\hline I able to work at group & $\mathrm{S} 2$ & & & \\
\hline My skill communication & S3 & 0.487 & & \\
\hline My conflict managerial skill & S4 & 0.573 & & \\
\hline My leadership skill & S5 & 0.640 & & \\
\hline My change management skill & S6 & 0.604 & & \\
\hline My skill of reading, writing and hearing & S7 & 0.418 & & \\
\hline My presentation skill & S8 & 0.497 & & \\
\hline My information technology skill & S9 & 0.473 & & \\
\hline My marketing skill & S10 & 0.509 & & \\
\hline My English & S11 & 0.382 & & \\
\hline My foreign language & S12 & 0.367 & & \\
\hline My interpersonal skill & S13 & 0.545 & & \\
\hline My emotional quotient & S14 & 0.602 & & \\
\hline My flexibility & S15 & 0.587 & & \\
\hline My career management & S16 & 0.638 & & \\
\hline My mindful leadership & S17 & 0.684 & & \\
\hline My networking skill & S18 & 0.651 & & \\
\hline My execution skill & S19 & 0.606 & & \\
\hline My entrepreneurship skill & $\mathrm{S} 20$ & 0.563 & & \\
\hline My innovation skill & $\mathrm{S} 21$ & 0.608 & & \\
\hline My creativity & $\mathrm{S} 22$ & 0.601 & & \\
\hline My social literacy & $\mathrm{S} 23$ & 0.607 & & \\
\hline My cross cultural skill & S24 & 0.602 & & \\
\hline My adversity skill & S25 & 0.549 & & \\
\hline My mentoring skill & S26 & 0.589 & & \\
\hline My skill of accelerated learning techniques & S27 & 0.600 & & \\
\hline My comprehensive thinking & $\mathrm{S} 28$ & 0.592 & & \\
\hline
\end{tabular}

K: Knowledge; S: Skill; CR: Competition Readiness

Table 4: Means, standard deviation, $\alpha$ value, loading factor, average variance extracted

\begin{tabular}{|c|c|c|c|c|c|c|c|}
\hline Construct/Items & Mean & SD & $\begin{array}{c}\text { Item-total } \\
>0.3 \text { (Dunn) }\end{array}$ & $\begin{array}{c}\alpha \text {-value }>0.7 \\
\text { (Churchill; Bagozzi and } \\
\text { Yi, Nunnally and Bernstein) }\end{array}$ & $\begin{array}{l}\text { Loading }>0.35 \\
\text { (Anderson and } \\
\text { Gerbing, 1988) }\end{array}$ & $\begin{array}{c}\text { CR } 0.5 \text { (basic), } \\
0.6 \text { (EFA), } 0.7 \\
\text { (Nunnally, Hair) }\end{array}$ & $\begin{array}{c}\text { AVE }>0.5 \\
\text { (Anderson and } \\
\text { Gerbing, 1988) }\end{array}$ \\
\hline \multicolumn{8}{|c|}{ Competitive readiness } \\
\hline CR1 & 5.027 & 1.932 & 0.709 & 0.830 & 0.830 & 0.797 & 0.659 \\
\hline \multirow{2}{*}{\multicolumn{8}{|c|}{ Knowledge }} \\
\hline & & & & & & & \\
\hline $\mathrm{K} 1$ & 2.580 & 0.546 & 0.697 & 0.807 & 0.806 & 0.781 & 0.545 \\
\hline K2 & & & 0.718 & & 0.759 & & \\
\hline K3 & & & 0.788 & & 0.639 & & \\
\hline \multicolumn{8}{|l|}{ Skill } \\
\hline S4 & 2.798 & 0.396 & 0.573 & 0.927 & 0.573 & 0.917 & 0.367 \\
\hline S5 & & & 0.635 & & 0.640 & & \\
\hline S6 & & & 0.596 & & 0.604 & & \\
\hline $\mathrm{S} 10$ & & & 0.498 & & 0.509 & & \\
\hline S13 & & & 0.548 & & 0.545 & & \\
\hline S14 & & & 0.611 & & 0.602 & & \\
\hline S15 & & & 0.592 & & 0.587 & & \\
\hline S16 & & & 0.642 & & 0.638 & & \\
\hline S17 & & & 0.681 & & 0.684 & & \\
\hline S18 & & & 0.636 & & 0.651 & & \\
\hline S19 & & & 0.612 & & 0.606 & & \\
\hline $\mathrm{S} 20$ & & & 0.558 & & 0.563 & & \\
\hline S21 & & & 0.610 & & 0.608 & & \\
\hline $\mathrm{S} 22$ & & & 0.610 & & 0.601 & & \\
\hline $\mathrm{S} 23$ & & & 0.617 & & 0.607 & & \\
\hline S24 & & & 0.594 & & 0.602 & & \\
\hline S25 & & & 0.554 & & 0.549 & & \\
\hline S26 & & & 0.590 & & 0.589 & & \\
\hline S27 & & & 0.602 & & 0.600 & & \\
\hline $\mathrm{S} 28$ & & & 0.605 & & 0.592 & & \\
\hline
\end{tabular}


The Soc. Sci., 12 (12): 2254-2259, 2017

Table 5: Correlation and Cronbach $\alpha$

\begin{tabular}{|c|c|c|c|c|c|c|c|c|}
\hline Variables & 1 & 2 & 3 & 4 & 5 & 6 & 7 & 8 \\
\hline \multicolumn{9}{|c|}{ Study program accreditation } \\
\hline Institution accreditation & $0.632^{\text {*** }}$ & & & & & & & \\
\hline Semester & -0.011 & 0.016 & & & & & & \\
\hline GPA & $-0.116^{* * *}$ & $-0.116^{* * *}$ & -0.022 & & & & & \\
\hline Gender & -0.036 & -0.013 & 0.012 & 0.038 & & & & \\
\hline Competition readiness & $-0.120^{\text {*** }}$ & $-0.096^{* * *}$ & -0.034 & $0.125^{* * *}$ & $-0.113^{* * *}$ & 0.830 & & \\
\hline Knowledge & -0.010 & -0.013 & -0.016 & $0.053^{*}$ & 0.008 & $0.281^{* * *}$ & 0.807 & \\
\hline$\underline{\text { Skill }}$ & $-0.042 *$ & -0.026 & -0.014 & $0.087^{* * *}$ & 0.014 & $0.281^{* * *}$ & $0.431^{* * *}$ & $0.927^{*}$ \\
\hline
\end{tabular}

${ }^{*}$ Correlation is significant at the 0.05 level (2-tailed); ${ }^{* *}$ Correlation is significant at the 0.01 level (2-tailed)

of AVE. Table 5 shows that the inter-correlation values for all paired latent variables are $>1.0$. Accordingly, the values of between variables do not overlap.

\section{RESULTS AND DISCUSSION}

This study found that knowledge $\left(\beta=0.177^{* * *}\right)$ and skill $\left(\beta=0.203^{* * *}\right)$ are significantly affect the readiness of AEC competition (Table 6). Sudents with a better knowledge and skill have a better readiness to compete toward the competition at Asean Economic Community (AEC). Knowledge and skill of student contribute $10.1 \%$ to explain the student's readiness to compete toward the competition at Asean Economic Community (AEC). It shows that to compete toward $\mathrm{AEC}$, Indonesian student need to improve their knowledge and skill in order to strengthen their readiness on AEC competition.

It is believed that self-efficacy play an important role on international interaction. Self-efficacy of student is belief of their abilities-knowledge and skill-to solve the problems (Bandura, 1977). It may help to encounter many cultural challenges when one is required to make an adjustment on her/his behavior and competencies. Scholars (McGee et al., 2009) found that Indonesian student self-efficacy is related to their intention to behave. It is promoted by tacit knowledge which is able to be a source of sustainable competitive advantage and by the mastery of relevant skill (Gist and Mitchell, 1992; Hsu et al., 2007). It is supported by the findig that GPA and their knowledge on MEA play as a motivational construct based on self perception of competence. It is found that GPA and their knowledge on MEA are able to encourage student's readiness to compete toward the competition at AEC. School-level variables such as accreditation status of study program is also related to the student's competition readiness. It may act as a contextual factor related self efficacy (Bandura, 1977).

Hence, it is plausible that students tend to show better evidence facing a competition when they have a better knowledge and skill, GPA, understand about MEA and graduate from better accretitation of their study program. However, the result of this study shows that
Table 6: The effect of knowledge and skill on the readiness of AEC competition

\begin{tabular}{|c|c|c|c|c|}
\hline Variables & $\beta$ step 1 & $\beta$ step 2 & $\beta$ step 3 & $\beta$ step 4 \\
\hline \multicolumn{5}{|l|}{ Controlled variables } \\
\hline Study program accreditation & $-0.074 * *$ & $-0.074^{* * *}$ & $-0.071^{* * *}$ & $-0.072^{* * *}$ \\
\hline Institution accreditation & -0.027 & -0.031 & -0.026 & -0.028 \\
\hline Semester & -0.008 & -0.004 & -0.014 & -0.010 \\
\hline GPA & $0.101^{\text {***** }}$ & $0.088^{\text {*****k }}$ & $0.079^{\text {***** }}$ & $0.076^{* * * * *}$ \\
\hline Gender & $-0.132^{* * * * *}$ & $-0.132^{* * * * *}$ & $-0.130^{\text {***** }}$ & -0.131 *** * \\
\hline Motivation for further study & $0.124^{* * * * * *}$ & $0.114^{* * * * * *}$ & $0.103^{* * * * *}$ & $0.102^{* * * *}$ \\
\hline Kowledge of MEA & $0.211^{\text {****⿲二丨匕 }}$ & $0.204^{\text {****** }}$ & $0.198^{* * * *}$ & $0.197^{* * * * *}$ \\
\hline \multicolumn{5}{|l|}{ Observe variables } \\
\hline Knowledge & & $0.261^{* * * * *}$ & & $0.177^{* * * *}$ \\
\hline Skill & & $0.277^{* * * * *}$ & $0.203^{* * * *}$ & \\
\hline $\mathrm{R}^{2}$ & 0.105 & 0.172 & 0.180 & 0.206 \\
\hline$\Delta \mathrm{R}^{2}$ & 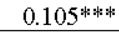 & $0.068^{\text {***k* }}$ & $0.075^{* * * * *}$ & $0.01^{\text {***; } * \text {; }}$ \\
\hline
\end{tabular}

accreditation of the student's institution and the level of their semester are not significant to affect their readiness to compete toward the competition at Asean economic community. This because the level of competitions of MEA are based on the agreement of its services sectors as well as the background of the study program of students.

\section{CONCLUSION}

The younger generation should have a good entrepreneurial spirit such as risk taking, creative and other competitive knowledge and skill (Imaroh, 2016; Ushakov, 2016). Accordingly, it is necessary to set up the readiness of students to deal with global AEC challenges of competitions.

\section{LIMITATIONS}

Notwithstanding these contributions, this study has its limitations. This study allows us to rule out Indonesian student's knowledge and skill to strengthen the evidence of readiness on AEC competition. However, it is open questions as to whether the results can be applied to different broader coverage of various sub conditions of competitions such as inter and intra new comer competition should become future attractive investigations. It might be expected to relate to $\mathrm{AEC}$ readiness of competition differently. Additional 
longitudinal study of competition readiness of competitive advantages growth is plausible. It will likely able to explain the prediction of knowledge and skill requirement on the future competitions. Measurement equivalence is now more than ever a general concern in organizational studies. Participants with different levels of support from their higher education institution and experimental versus control groups are highly recomended for further studies.

\section{REFERENCES}

Anderson, J.C. and D.W. Gerbing, 1988. Structural equation modeling in practice: $\mathrm{A}$ review and recommended two-step approach. Psychol. Bull., 103: 411-423.

Babushkina, G.D., A.P. Shumilinb and A.I. Chikurovb, 2011. Diagnostics and correction of pre-competition psychological readiness of judoists of dif-ferent qualifications. J. Siberian Federal Univ. Hum. Soc. Sci., 9: 1240-1250.

Bandura, A., 1977. Self-efficacy: Toward a unifying theory of behavioral change. Psychol. Rev., 84: 191-215.

Blumenstein, B. and I. Orbach, 2016. Professional coach: The link between science and media. Sport Sci. Rev., 25: 73-84.

Findlay, C. and M. Pangestu, 2016. The services sector as a driver of change: Indonesia's experience in the ASEAN context. Bull. Indonesian Econ. Stud., 52: 27-53.

Firmin, M.W., J.E. Lucius and S. Johnson, 2011. Student perspectives of competition: A qualitative analysis. Am. J. Bus. Educ., 2: 7-15.

Fornell, C. and D.F. Larcker, 1981. Structural equation models with unobservable variables and measurement error: Algebra and statistics. J. Market. Res., 18: 382-388.

Gist, M.E. and T.R. Mitchell, 1992. Self-efficacy: A theoretical analysis of its determinants and malleability. Acad. Manage. Rev., 17: 183-211.

Hsu, M.H., T.L. Ju, C.H. Yen and C.M. Chang, 2007. Knowledge sharing behavior in virtual communities: The relationship between trust, self-efficacy and outcome expectations. Int. J. Hum. Comp. Studies, 65 : 153-169.
Imaroh, T.S., 2016. Entrepreneurship education as a strategy for improving the economical independence and competitive ability of society in asean economic community (aec) era. Intl. J. Organizational Innovation, 9: 287-294.

Kee, L.H., A. Nicita and M. Olarreaga, 2009. Estimating trade restrictiveness indices. Econ. J., 119: 172-199.

Maire, L.J., S.E. Short, R.L. Stewart and M.W. Short, 2007. The effect of uniform color on athletes readiness for competition and perceptions of opponents attributes. J. Sport Exercise Psychol., 29: 180-181.

McGee, J.E., M. Peterson, S.L. Mueller and J.M. Sequeira, 2009. Entrepreneurial self-efficacy: Refining the measure. Entrepreneurship Theory Pract., 33: 965-988.

Mishra, A.K., G. Rao, A. Monga and B. Vishwanath, 2016. Assessing competitiveness in emerging Asian economies: Role of governance and infrastructure and lessons for India. Emerging Economy Stud., 2: 72-90.

Papademetriou, D.G., G. Sugiyarto, D.R. Mendoza and B. Salant, 2016. Achieving Skill Mobility in the ASEAN Economic Community: Challenges, Opportunities and Policy Implications. Asian Development Bank, Mandaluyong, Philippines, ISBN:9789292571177,.

Soesastro, H., 2003. An ASEAN Economic Community and ASEAN+ 3: How do they Fit Together?. University of California, Oakland, California, ISBN:9780864132901,.

Soesastro, H., 2008. Implementing the ASEAN Economic Community (AEC) Blueprint. In: Deepening Economic Integration The ASEAN Economic Community and Beyond-, ERIA Research Project Report 2007-1-2, Soesastro, H. (Ed.). IDE-JETRO, Chiba, Japan, pp: 47-59.

Sumano, B., 2013. Explaining the liberalisation of professional migration in ASEAN. Ph.D Thesis, School of Politics and International Relations, University of London, London, England.

Ushakov, D.S., 2016. Innovative climate development as a factor for national economy progress (the case of Thailand). Actual Prob. Econ., 175: 94-104.

Vuong, Q.H., N.K. Napier, H.K. Vu, M.C. Nguyen and T.D. Tran, 2014. Measuring corporate innovation capacity: Experience and implications from i2Metrix implementation in Vietnam. ASEAN. J. Manage. Inf., 1: $1-17$. 